\title{
МОРФОМЕТРИЧНІ ПОКАЗНИКИ СУГЛОБОВОГО ПОКРИТТЯ КОМПОНЕНТІВ КОЛІННОГО СУГЛОБА В НОРМІ, НА РІЗНИХ ТЕРМІНАХ ОПІОЇДНОГО ВПЛИВУ ТА ПРИ ВІДМІНІ
}

\author{
Войценко К. І., Пальтов С. В., Кривко Ю. Я., Фік В. Б. \\ Львівський національний медичний університет імені Данила Галицьького, кафедра нормальної \\ анатомії, м. Львів, Україна
}

DOI: https://doi.org/10.31435/rsglobal_ws/31032019/6406

\section{ARTICLE INFO}

Received: 14 January 2019

Accepted: 25 March 2019

Published: 31 March 2019

\section{KEYWORDS}

morphometry, opioid, experiment, rat.

\begin{abstract}
The work, presented below, describes the findings of the study of emergence and gradual increase of manifestations of violation of the morphometric indices of the articular cartilage in the distal epiphysis of the femur and proximal epiphyses of the tibia at different terms of experimental opioid exposure (in norm, at the end of the 1st, 2nd, 3rd, 4th, 5th, and 6th weeks and after a two-week withdrawal at the end of the 8th week. The goal was achieved using the morphometric method of measuring the layers of the articular cartiliage of the distal epiphysis of the femur and proximal epiphyses of the tibia in histological preparations obtained at different terms of experimental opioid exposure. Histologic preparations were obtained by applying a generally accepted method.

The results of this research will form pathomorphometric basis, which can be applied for a comparative analysis of the dynamics of emergence, development and gradual increase of change in morphometric indices of structural components of the articular cartilage at early stages.
\end{abstract}

Citation: Войценко К. І., Пальтов С. В., Кривко Ю. Я., Фік В. Б. (2019) Morfometrychni Pokaznyky Suhlobovoho Pokryttia Komponentiv Kolinnoho Suhloba v Normi, na Riznykh Terminakh Opioidnoho Vplyvu ta pry Vidmini. World Science. 3(43), Vol.2. doi: 10.31435/rsglobal_ws/31032019/6406

Copyright: (C) 2019 Войценко К. І., Пальтов С. В., Кривко Ю. Я., Фік В. Б. This is an open-access article distributed under the terms of the Creative Commons Attribution License (CC BY). The use, distribution or reproduction in other forums is permitted, provided the original author(s) or licensor are credited and that the original publication in this journal is cited, in accordance with accepted academic practice. No use, distribution or reproduction is permitted which does not comply with these terms.

Результати статі відповідають плану наукових досліджень Львівського національного медичного університету імені Данила Галицького і $є$ частиною науково - дослідної теми кафедри нормальної анатомії «Структурна організація, ангіоархітектоніки та антропометричні особливості органів у внутрішньо та позаутробному періодах розвитку, за умов екзо- та ендопатогених факторів» (номер держреєстрації 0115U000041) впродовж 2015 - 2019 pp.

Вступ. Описовий характер процесів розвитку патоморфологічних змін у шарах хряшового покриття дистального відділу стегнової та проксимального відділу великогомілкової кістки при експериментальному опіоїдному впливі не завжди $є$ достатнім для глибокого аналізу сутності явищ, термінів появи та темпів наростання патоморфологічних змін на різних термінах протікання експериментальної патології . Саме тому, залишаючи базовими традиційні методи ресстрації морфологічних змін, нами використано методи математичної обробки отриманих даних. Такий підхід до вивчення описуваних явищ, значно полегшує розуміння процесів та логіку доказів [1-5].

Вищезазначене окреслело мету нашої роботи, що полягала у вивченні особливостей зміни морфометричних показників хрящового покриття дистального відділу стегнової та проксимального відділу великогомілкової кісток на різних термінах перебігу експериментального опіоїдного впливу.

Матеріали та методи дослідження. Матеріалом дослідження слугували статево зрілі, безпородні щури-самці в кількості 32-ві тварини, масою 80 - 135 г, віком 4,5 місяців. Тваринам 
проводили ін'єкції препарату налбуфін дом'язево, щоденно 1 раз на добу в одному проміжку часу (10-11 година ранку) впродовж 42 діб. Початкова доза налбуфіну становила 8 мг/кг впродовж першого тижня, 15 мг/кг впродовж другого тижня, 20 мг/кг впродовж третього тижня, 25 мг/кг впродовж четвертого тижня, 30 мг/кг впродовж п'ятого тижня та 35 мг/кг впродовж шостого тижня. Таким чином створювали умови хронічного опіоїдного впливу [6]. Тварини поділені на 2 групи. 1- а група тварин отримувала налбуфін протягом 42 діб в одному проміжку часу (10-11 годин ранку) 3 наступним забором матеріалу дослідження. 2-a контрольна, яка протягом 56 діб отримувала ін'єкції фізіологічного розчину дом'язево в одному проміжку часу (10-11 годин ранку) з подальшим забором матеріалу. Усі тварини знаходились в умовах віварію і робота, що стосувалася питань утримання, догляду, маркування та всі інші маніпуляції проводилися із дотриманням положень “ Свропейської конвенції про захист хребетних тварин, які використовуються для експериментальних та інших наукових цілей " [Стразбург, 1985], “ Загальних етичних принципів експериментів на тваринах ”, ухвалених Першим Національним конгресом з біоєтики [Київ, 2001]. Комісією з біоєтики Львівського національного медичного університету імені Данила Галицького встановлено, що проведені наукові дослідження відповідають етичним вимогам згідно наказу МОЗ України № 231 від 01.11.2000 року (протокол № 10 від 26.12.2011 року). Перед проведенням забору біопсійного матеріалу тварину присипляли дибутиловим ефіром. Як матеріал для морфометричного дослідження використали хрящі дистального епіфізу стегнової та проксимального епіфізу великогомілкової кісток колінного суглоба щурів на гістологічних зрізах [7-12]. Гістологічні препарати готували за загальноприйнятою методикою [13].

Результати дослідження. На основі проведеного морфометричного дослідження встановлено товщину (хряща стегнової кістки в дистальному відділі, товщину зони росту стегнової кістки в дистальному відділі, товщину хряща великогомілкової кістки в проксимальному відділі та товщину зони росту великогомілкової кістки в проксимальному відділі). Дані отриманих значень опрацьовано статистично і подано в таблиці та висвітлено в діаграмі (Таблиця 1, Діаграма 1.). Товщина хряща стегнової кістки щурів контрольної групи була найбільшою в ділянці контакту із великогомілковою кісткою та становила 160-180 мкм. Найменша товщина хряща стегнової кістки була у фронтальній ділянці в зоні контакту із надколінником та становила 70-90 мкм. Середнє значення товщини хряща стегнової кістки у тварин контрольної групи становило $144,88 \pm 31,20$ мкм. Зона росту стегнової кістки інтактних тварин на розрізі мала зубчасту форму із коливанням товщини від 97,56 мкм до 315,65 мкм при середньому значенні $213,90 \pm 45,34$ мкм.

Таблиця.1. Морфометричні показники стегнової та великогомілкової кісток щурів контрольної групи.

\begin{tabular}{|l|c|c|c|c|c|}
\hline Групи & $\mathrm{M}$ & $\mathrm{SD}$ & $\mathrm{Min}$ & $\mathrm{Max}$ & $\mathrm{N}$ \\
\hline Стегнова хрящ & 144,88 & 31,20 & 72,23 & 219,97 & 81 \\
\hline Стегнова зона росту & 213,90 & 45,35 & 97,56 & 315,65 & 71 \\
\hline Великогомілкова хрящ & 158,22 & 46,72 & 96,09 & 241,96 & 51 \\
\hline Великогомілкова зона росту & 278,10 & 57,90 & 180,72 & 492,54 & 63 \\
\hline
\end{tabular}

M - середнє значення, SD - стандартне відхилення, Min- мінімальне значення показника у цій групі, Мах- максимальне значення показника у цій групі, N- об’єм вибірки.

Товщина хряща великогомілкової кістки була найбільшою в центральній частині надвиростків (у зоні контакту із стегновою кісткою) - тут вона досягала показників 230-240 мкм. У периферійних ділянках надвиростків товщина хряща зменшувалась до показників 100 110 мкм. Середнє значення показника товщини хряща великогомілкової кістки становило $158,22 \pm 46,72$ мкм. Різниця товщини хряща великогомілкової кістки та стегнової є статистично значущою $(\mathrm{p}<0,001, \mathrm{t}=4,42)$. Зона росту великогомілкової кістки щурів контрольної групи на розрізі мала прямолінійну форму. Товщина зони росту коливалась від 180,72мкм до 492,54 мкм при середньому значенні $278,10 \pm 57,90$ мкм. Різниця товщини зони росту великогомілкової кістки та стегнової є статистично значущою ( $<0,001, \mathrm{t}=8,90)$. 


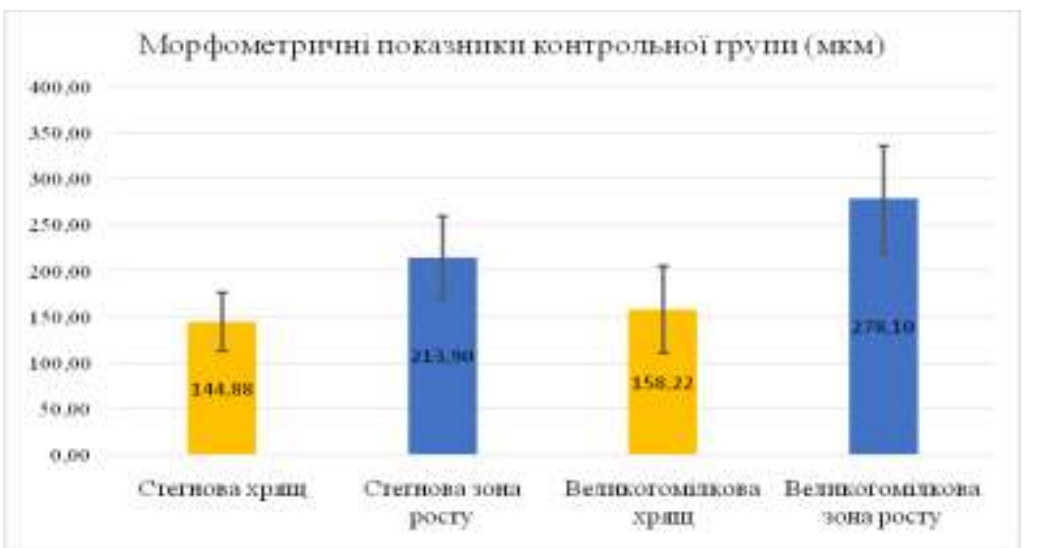

Діаграма 1. Діаграма результатів морфометричного аналізу великогомілкової та стегнової кісток контрольної групи.

На основі проведеного морфометричного дослідження гістологічних препаратів хрящового покриття колінного суглоба щурів наприкінці першого тижня експериментального опіоїдного впливу виявлено рівномірне потовщення хряща великогомілкової та стегнової кісток переважно за рахунок вакуолізації та набряку внутрішнього шару. Товщина хряща стегнової кістки була найменшою в ділянках контакту із надколінником і коливалась тут в межах 80-150 мкм. В той же час товщина в ділянці контакту із великогомілковою кісткою становила 250-320 мкм. Середнє значення товщини хряща стегнової кістки наприкінці першого тижня експериментального опіоїдного впливу становило 150,22 40,18 мкм. Однак, незважаючи на тенденцію до збільшення товщини, різниця не була підтверджена статистично при порівнянні із показником контрольної групи ( $=0,35$ при $\mathrm{t}=-0,95)$. Товщина хряща великогомілкової кістки коливалась в межах від 91,19 мкм до 275,74 мкм при середньому значенні $179,94 \pm 47,54$ мкм. Різниця при порівнянні із показниками контрольної групи була статистично достовірною $(\mathrm{p}<0,05, \mathrm{t}=-2,62)$. Зона росту великогомілкової кістки у тварин наприкінці першого тижня експериментального опіоїдного впливу була нерівномірною - в окремих зразках зустрічаються ділянки потовщення до 500600 мкм, а в поодиноких випадках - до 800 мкм (максимальне значення 826,54 мкм). Мінімальне значення становило 203,90 мкм, що було значно більше показника контрольної групи. Середнє значення становило $346,74 \pm 138,99$, що було достовірно більше за показник контрольної групи $(\mathrm{p}<0,001, \mathrm{t}=-3,43)$. Зона росту стегнової кістки мала нерівномірну товщину, що коливалась від 111,34 мкм до 403,86 мкм. Зовнішня межа була хвилястою за формою, утворюючи вип'ячування в сторону епіфізу. Середнє значення товщини зони росту стегнової кістки щурів наприкінці першого тижня експериментального опіоїдного впливу становило $220,73 \pm 71,91$. I хоча таке збільшення не було підтверджено статистично ( $\mathrm{p}=0,51, \mathrm{t}=-0,67)$, однак тенденція до потовщення підтверджується не тільки збільшенням середнього значення, але і значним збільшенням показника стандартного відхилення до 71,91 (45,34 у щурів контрольної групи. На основі проведеного морфометричного дослідження гістологічних препаратів хрящового покриття колінного суглоба щурів наприкінці другого тижня експериментального опіоїдного впливу виявлено, що товщина хряща стегнової кістки продовжувала збільшуватись і досягла середнього значення 194,24 $\pm 72,03$ мкм (у контрольної групи $144,88 \pm 31,20$ мкм, різниця статистично значуща, $\mathrm{p}<0,001, \mathrm{t}=-5,37)$. Максимальне потовщення спостерігалась в ділянці контакту із великогомілковою кісткою, тут показник товщини коливався в межах 200-320 мкм із максимальним значенням 349,77мкм. У ділянці контакту із надколінником товщина збільшувалась не так виражено і коливалась у межах 95-110 мкм із мінімальним показником 91,47 мкм. Товщина хряща великогомілкової кістки залишалась на рівні показника попереднього терміну - iї середнє значення становило $174,99 \pm 38,64$ мкм, хоча цей показник і не був достовірно більшим за значення контрольної групи $(\mathrm{p}=0,08, \mathrm{t}=-1,77)$ при достатньо великій фактичній різниці, що можна пояснити низькою статистичною потужністю нашої вибірки. Зона росту стегнової кістки і надалі мала тенденцію до збільшення товщини, що призвело до збільшення

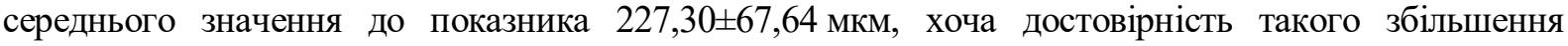

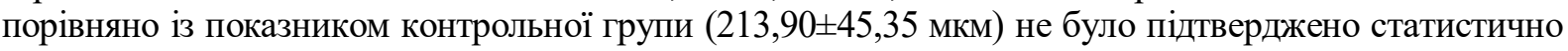
$-\mathrm{p}=0,15, \mathrm{t}=1,46$. Однак в окремих ділянках розшарування та потовщення зони росту призводило до збільшення товщини до 350-450 мкм із максимальним значенням у 465,22 мкм (максимальний показник товщини контрольної групи становив 315,65 мкм). Товщина зони росту великогомілкової кістки наприкінці другого тижня експериментального опіоїдного впливу різко знизилась після 
збільшення цього показника на попередньому терміні. Середнє значення становило $246,51 \pm 43,70$ мкм, що було значено менше показника наприкінці першого тижня експерименту, яке становило 346,74 $\pm 139,00$ мкм, та навіть дещо менше показника контрольної групи $(278,10 \pm 57,90$ мкм). Таке зменшення в порівнянні із показником контрольної групи було підтверджено статистично - показник $\mathrm{p}<0,001$ при $\mathrm{t}=3,92$. На основі проведеного морфометричного дослідження гістологічних препаратів хрящового покриття колінного суглоба щурів наприкінці третього тижня експериментального опіоїдного впливу виявлено, що стегнова кістка-хрящ нерівномірний, 3 ділянками потовщення до 180-240 мкм (максимальний показник 244,24 мкм) та стоншення до 60-70 мкм (мінімальний показник 57,74 мкм). Середнє значення товщини хряща стегнової кістки різко знизилося, як в порівнянні із показником попереднього терміну

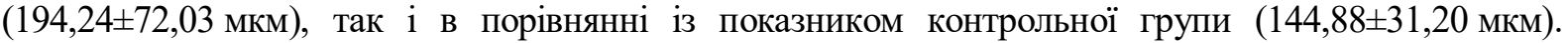
Зниження в порівнянні із показником контрольної групи було статистично значущім $-p<0,05$, $\mathrm{t}=2,59$. Показники товщини хряща великогомілкової кістки також демонструють динаміку зниження в порівнянні з попередніми термінами фактично до значення показника контрольної

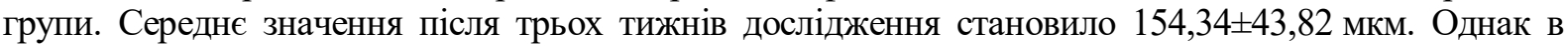
окремих ділянках залишались потовщення 200-250 мкм (максимальний показник 271,96 мкм, при максимальному показнику контрольної групи 241,96 мкм). Зона росту стегнової кістки та великогомілкової мають хвилясту форму із нерівномірними вип'ячуваннями в напрямку епіфізу, що найбільше виражено в стегновій кістці - тут потовщення досягають показників 300-350 мкм при максимальному значенні 396,83 мкм (у тварин контрольної групи максимальне значення цього показника становило 315,65 мкм). Середнє значення показника товщини зони росту стегнової

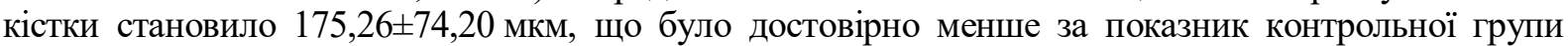
$(\mathrm{p}<0,001, \mathrm{t}=3,97)$. Середне значення показника товщини зони росту великогомілкової кістки після

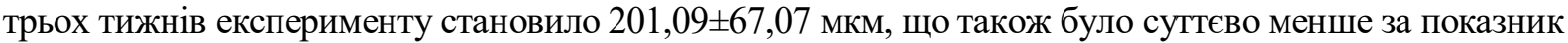
контрольної групи і підтверджувалось статистично ( $<20,001$ при $\mathrm{t}=7,41)$. На основі проведеного морфометричного дослідження гістологічних препаратів хрящового покриття колінного суглоба щурів наприкінці четвертого тижня експериментального опіоїдного впливу виявлено, що у передній ділянці переходу в зону росту, що наближена до точки прикріплення зв'язки надколінка, товщина хряща великогомілкової кістки була найбільшою і досягала показників 300-400 мкм із максимальним значенням 512,67 мкм. В окремих зразках товщина хрящів стегнової та великогомілкової кісток була рівномірною, тоді як в інших хвилеподібно коливалась від 90 до 250 мкм у великогомілкової кістки та від 90 до 350 мкм у стегнової. Середнє значення товщини хряща стегнової кістки на цьому терміні дослідження становило 137,34 $\pm 50,34$ мкм, великогомілкової кістки - 156,93 47,57 мкм, що в обох випадках було наближене до показників контрольної групи і не мало статистично достовірної різниці. Зона росту стегнової кістки лише в одному зразку була рівномірною із коливанням товщини від 150 до 175 мкм. У більшості зразків зона росту стегнової кістки була нерівномірно потовщеною до 300-350 мкм із максимальним показником 528,22 мкм як це видно на рис.1. Така нерівномірність потовщення підтверджується різким збільшенням значення стандартного відхилення до 101,51 (у контрольній групі 45,35), хоча показник середнього значення хряща стегнової кістки на цьому терміні дослідження наближений до значення контрольної групи i становить 209,13 $\pm 101,51$ мкм. Товщина зони росту великогомілкової кістки мала тенденцію до збільшення в порівнянні із попереднім терміном, однак залишалась меншою за показник контрольної групи - іï значення становило 221,51 $\pm 50,53$ мкм, що було достовірно менше при порівнянні із групою контролю - $<<0,001$ при $\mathrm{t}=5,50$.

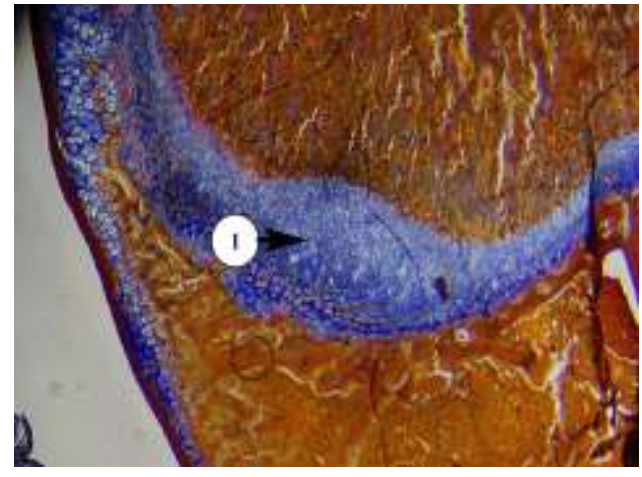

Рис. 1. Потовщуення (1) ділянки зони росту стегнової кістки наприкінці четвертого тижня експериментального опіоїдного впливу. 
На основі проведеного морфометричного дослідження гістологічних препаратів хрящового покриття колінного суглоба щурів наприкінці п'ятого тижня експериментального опіоїдного впливу виявлено, що характерним є хвилеподібний малюнок зони росту стегнової кістки та великогомілкової кістки із різкими випинами в сторону епіфізу, що досягають показників 400500 мкм у стегнової та 300-360 у великогомілкової кістки. Максимальне значення зони росту стегнової кістки становило 542,19 мкм, а середній показник різко збільшився як у порівнянні із попереднім терміном, так і при порівнянні із контрольною групою, досягнувши значення $249,20 \pm 79,99$ мкм. Збільшення є достовірним у порівнянні із контрольною групою - $<<0,001$ при $\mathrm{t}=3$,98.Середнє значення товщини великогомілкової кістки лишилось на рівні попереднього терміну і становило $223.98 \pm 67.85$ мкм, що було достовірно менше за показник контрольної групи ( $<<0,001$ при $\mathrm{t}=5,31)$. Хрящ стегнової кістки - переважно рівномірної товщини, лише в передній ділянці переходу в зону росту спостерігалось потовщення до 280-320 мкм. При цьому середне значення товщини хряща стегнової кістки на цьому терміні має тенденцію до зменшення як у порівнянні із попереднім терміном, так i y порівнянні із показником контрольної групи і становить $118,72 \pm 51,21$ мкм, що $є$ достовірно менше показника контрольної групи ( $<00,001$ при $\mathrm{t}=3,98)$. Хрящ великогомілкової має більшу тенденцію до варіативності товщини - нерівномірності форми у перерізі із потовщеннями до 260-380 мкм, а в окремих зразках товщина досягала 500 мкм. За рахунок цього середне значення товщини хряща великогомілкової кістки зросло до $188,47 \pm 96,62$ мкм, при максимальному показнику 502,94 мкм. Таке збільшення було статистично достовірним при порівнянні із показником контрольної групи ( $<0,05$ при $\mathrm{t}=-2,07)$. На основі проведеного морфометричного дослідження гістологічних препаратів хрящового покриття колінного суглоба щурів наприкінці шостого тижня експериментального опіоїдного впливу виявлено, що зберігається нерівномірність зони росту стегнової кістки за товщиною із коливаннями від мінімального значення 81,81 мкм до максимального 460,10 мкм, часто із хвилеподібним малюнком та випинами як в сторону діафізу, так і в сторону епіфізу як це показано на рис. 2., що пояснює різке збільшення стандартного відхилення до 107,14 мкм. При цьому показник середнього значення товщини зони росту стегнової кістки на цьому терміні експерименту становив 242,21 мкм, що було достовірно більше за показник контрольної групи ( $<0,05$ при $\mathrm{t}=-2,00)$. Зона росту великогомілкової кістки має більш рівномірний характер за товщиною, що підтверджується невеликим значенням стандартне відхилення - 42,98 мкм, однак має також хвилеподібний малюнок із незначними випинами як у сторону епіфізу, так і в сторону діафізу. Хрящ стегнової кістки характеризувався подальшою тенденцією до рівномірного зменшення товщини, лише в окремих ділянках спостерігались випини в сторону епіфізу товщиною до 150-170 мкм. Максимальне значення товщини хряща стегнової кістки становило 172,37 мкм, мінімальне - 52,06 мкм. Середнє значення товщини хряща стегнової кістки на цьому терміні дослідження становило $104.13 \pm 27.42$ мкм, що було достовірно менше за показник контрольної групи ( $<<0,001$ при $t=8,15)$ i мало найменше значення протягом експерименту.

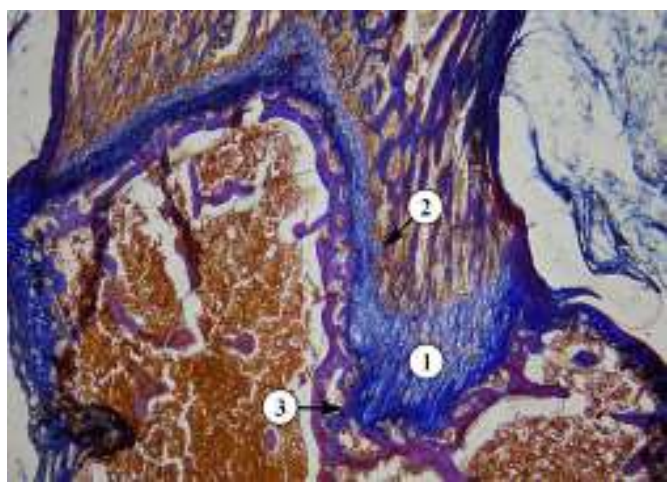

Рис. 2. Потовщення (1) та випини $(2,3)$ ділянки зони росту стегнової кістки наприкінці шостого тижня експерниментального опіоїдного впливу.

Хрящ великогомілкової кістки навпаки - мав нерівномірний характер за товщиною, значення якої коливається від мінімального значення 65,84 мкм до максимального - 554,66 мкм, із окремими ділянками різкого потовщення 3 нерівномірними випинами в сторону епіфізу, найчастіше в центральній частині та в передній ділянці переходу в зону росту. Середнє значення товщини хряща великогомілкової кістки становило $186,54 \pm 89,79$ мкм. В результаті проведеного забору експериментального матеріалу наприкінці восьмого тижня у шурів, що знаходилися впродовж двотижневої відміни опіоїду на морфометричному рівні нами було виявлено, що показники хряща 
стегнової кістки мали рівномірну товщину із коливаннями від мінімального значення 78,09 мкм до

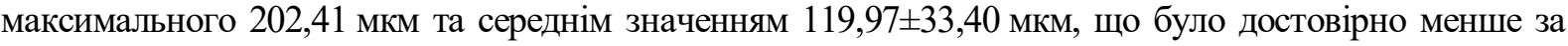
показник контрольної групи ( $<0,001$ при $\mathrm{t}=4,39)$. Випинів не спостерігали. Показники хряща великогомілкової кістки мали рівномірне потовщення у центральній ділянці надвиростків. Форма поверхонь на перерізі переважно рівна, подібна до такої у контрольної групи, лише в окремих ділянках спостерігались невелики випини хряща в сторону епіфізу та фокальна вакуолізація клітин внутрішнього шару. Товщина хряща великогомілкової кістки в передній ділянці переходу в зону росту, що наближена до точки прикріплення зв'язки надколінка, коливалась в межах 200-330 мкм. Середне значення товщини хряща великогомілкової кістки на 8-й тиждень становило $135,20 \pm 54,24$ мкм із коливанням від мінімального значення 35,79 мкм до максимального 333,16 мкм. Такий показник був достовірно меншим за показник контрольної групи ( $<<0,05$ при $t=2,57)$. Показники зони росту великогомілкової кістки були переважно рівномірними за товщиною, лише в окремих ділянках епіфізарної поверхні зберігається хвилеподібний малюнок із потовщеннями до 240300 мкм при середньому значенні товщини показників зони росту великогомілкової кістки $181,87 \pm 44,86$ мкм. Такий показник був достовірно меншим за показник контрольної групи ( $<0,001$ при $\mathrm{t}=11,57)$. Більш нерівномірною за формою на цьому терміні експерименту була зона росту

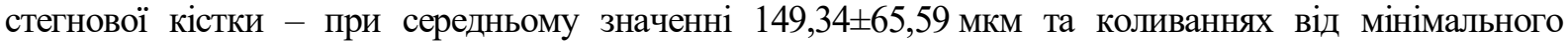
показника у 64,98 мкм до максимального 345,96 мкм зберігалась хвилеподібна форма як діафізарної так і епіфізарноїчастини зони росту із стазом еритроцитів та діапедезними крововиливами в ділянках діафізу, наближених до зони росту. При цьому середнє значення було достовірно меншим за показник контрольної групи ( $<<0,001$ при $t=5,35)$. Всі показники були менше показників контрольної групи. В цілому протягом експерименту морфометричні показники хрящів та зон росту кісток щура мають різні тенденції протягом перших термінів із загальною тенденцією до зменшення середніх значень після 3-х тижнів дослідження 3 подальшим переважно наростанням товщини протягом наступних термінів (виключення товщина хряща стегнової кістки, яка зберігає стійку тенденцію до стоншення після 2 - го тижня експерименту). Після відміни, на 8 - му тижні дослідження, всі параметри мали різке достовірне зменшення у порівнянні із показниками контрольної групи. В контексті вищесказаного особливо показовими $є$ зміни в місці передньої ділянки переходу хряща великогомілкової кістки в зону росту як це показано на рис. 3. На рисунку чітко видно динаміку як зони росту (2) великогомілкової кістки, так і ії хряща (1) протягом експерименту.

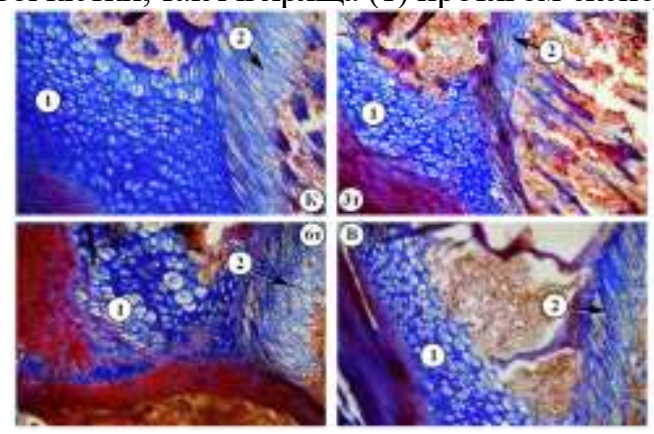

Рис. 3. Ділянка хряща (1) та зони росту (2) великогомілкової кістки контрольної групи (К), після 3 тижнів експерименту (3m), після 6 тижнів експерименту (6m) та після відміни (B).

Таблиця. 2. Динаміка показників товщини хряща стегнової кістки.

\begin{tabular}{|c|c|c|c|c|c|c|c|}
\hline Групи & $\mathrm{M}$ & $\mathrm{SD}$ & $\mathrm{Min}$ & $\mathrm{Max}$ & $\mathrm{N}$ & $\mathrm{p}$ & $\mathrm{t}$ \\
\hline Контроль & 144.88 & 31.2 & 72.23 & 219.97 & 81 & & \\
\hline 1_тиждень & 150.22 & 40.19 & 81.56 & 320.04 & 82 & 0.35 & -0.95 \\
\hline 2_тиждень & 194.24 & 72.03 & 91.47 & 349.77 & 47 & $<0,001$ & -5.37 \\
\hline 3 тиждень & 128.31 & 45.33 & 57.74 & 244.24 & 62 & 0.01 & 2.59 \\
\hline 4_тиждень & 137.34 & 50.34 & 73.73 & 363.78 & 94 & 0.24 & 1.17 \\
\hline 5_тиждень & 118.72 & 51.21 & 58.94 & 317.17 & 90 & $<0,001$ & 3.98 \\
\hline 6_тиждень & 104.13 & 27.42 & 52.06 & 172.37 & 62 & $<0,001$ & 8.15 \\
\hline Відміна & 119.97 & 33.40 & 78.09 & 202.41 & 53 & $<0,001$ & 4.39 \\
\hline
\end{tabular}

M - середнє значення, SD - стандартне відхилення, Min- мінімальне значення показника у цій групі, Мах- максимальне значення показника у цій групі, N- об'єм вибірки, $\mathrm{p}$ - точне значення $\mathrm{p}, \mathrm{t}$ - точне значення t-критерію. 
Таблиця. 3. Динаміка показників товщини хряща великогомілкової кістки.

\begin{tabular}{|c|c|c|c|c|c|c|c|}
\hline Групи & $\mathrm{M}$ & $\mathrm{SD}$ & $\mathrm{Min}$ & $\mathrm{Max}$ & $\mathrm{N}$ & $\mathrm{p}$ & $\mathrm{t}$ \\
\hline Контроль & 158.22 & 46.72 & 96.08 & 241.96 & 51 & & \\
\hline 1_тиждень & 179.94 & 47.54 & 91.19 & 275.74 & 90 & 0.01 & -2.62 \\
\hline 2_тиждень & 174.99 & 38.64 & 83.94 & 285.48 & 36 & 0.08 & -1.77 \\
\hline 3_тиждень & 154.34 & 43.82 & 81.30 & 271.33 & 40 & 0.69 & 0.41 \\
\hline 4_тиждень & 156.93 & 47.57 & 68.68 & 512.67 & 58 & 0.88 & 0.14 \\
\hline 5_тиждень & 188.47 & 96.62 & 62.18 & 502.94 & 70 & 0.041 & -2.07 \\
\hline 6_тиждень & 186.54 & 89.79 & 65.85 & 554.66 & 95 & 0.04 & -2.10 \\
\hline Відміна & 135.20 & 54.24 & 35.79 & 333.16 & 97 & 0.01 & 2.57 \\
\hline
\end{tabular}

M - середнє значення, SD - стандартне відхилення, Min - мінімальне значення показника у цій групі, Мах - максимальне значення показника у цій групі, N - об’єм вибірки, p - точне значення $\mathrm{p}, \mathrm{t}$ - точне значення $\mathrm{t}$-критерію.

Таблиця. 4. Динаміка показників товщини зони росту стегнової кістки.

\begin{tabular}{|l|r|r|r|r|r|r|c|}
\hline Групи & \multicolumn{1}{c|}{ M } & \multicolumn{1}{c|}{ SD } & \multicolumn{1}{c|}{ Min } & Max & N & \multicolumn{1}{c|}{$\mathrm{p}$} & $\mathrm{t}$ \\
\hline Контроль & 213.9 & 45.35 & 97.56 & 315.65 & 71 & & \\
\hline 1_тиждень & 220.73 & 71.91 & 111.34 & 403.86 & 64 & 0,51 & $-0,67$ \\
\hline 2_тиждень & 227.30 & 67.64 & 94.31 & 465.22 & 104 & 0,15 & $-1,46$ \\
\hline 3_тиждень & 175.26 & 74.20 & 60.49 & 396.83 & 119 & $<0,001$ & 3,97 \\
\hline 4_тиждень & 209.13 & 101.51 & 65.22 & 528.22 & 93 & 0.71 & 0.37 \\
\hline 5_тиждень & 249.20 & 79.99 & 96.28 & 542.19 & 96 & $<0,001$ & -3.34 \\
\hline 6_тиждень & 242.21 & 107.14 & 81.81 & 460.10 & 53 & 0.047 & -2.00 \\
\hline Відміна & 149.34 & 65.59 & 64.98 & 345.96 & 24 & $<0,001$ & 5.35 \\
\hline
\end{tabular}

M - середнє значення, SD - стандартне відхилення, Min - мінімальне значення показника у цій групі, Мах - максимальне значення показника у цій групі, $\mathrm{N}$ - об’єм вибірки, p - точне значення $\mathrm{p}, \mathrm{t}$ - точне значення $\mathrm{t}$-критерію.

Таблиця 5.Динаміка показників товщини зони росту великогомілкової кістки.

\begin{tabular}{|l|r|r|r|r|r|r|c|}
\hline Групи & \multicolumn{1}{|c|}{ M } & \multicolumn{1}{c|}{ SD } & \multicolumn{1}{c|}{ Min } & Max & N & p & t \\
\hline Контроль & 278.1 & 57.90 & 180.72 & 492.54 & 63 & & \\
\hline 1_тиждень & 346.74 & 139.00 & 203.90 & 826.54 & 35 & $<0,001$ & -3.43 \\
\hline 2_тиждень & 246.51 & 43.70 & 96.94 & 342.25 & 97 & $<0,001$ & 3.92 \\
\hline 3_тиждень & 201.09 & 67.07 & 100.22 & 429.83 & 92 & $<0,001$ & 7.41 \\
\hline 4_тиждень & 221.51 & 50.53 & 115.55 & 315.77 & 51 & $<0,001$ & 5.50 \\
\hline 5_тиждень & 223.98 & 67.85 & 101.87 & 456.61 & 109 & $<0,001$ & 5.31 \\
\hline 6_тиждень & 263.66 & 42.98 & 177.71 & 347.91 & 58 & 0.12 & 1.55 \\
\hline Відміна & 181.87 & 44.86 & 97.71 & 336.96 & 90 & $<0,001$ & 11.57 \\
\hline
\end{tabular}

M - середнє значення, SD - стандартне відхилення, Min - мінімальне значення показника у цій групі, Мах - максимальне значення показника у цій групі, $\mathrm{N}$ - об’єм вибірки, p - точне значення $\mathrm{p}, \mathrm{t}$ - точне значення $\mathrm{t}$-критерію.

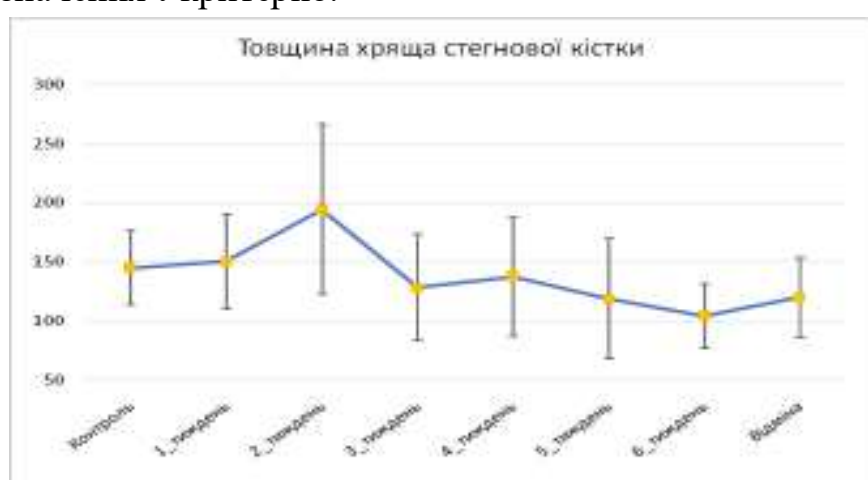

Діаграма.2. Динаміка значення товщини хряща стегнової кістки. 


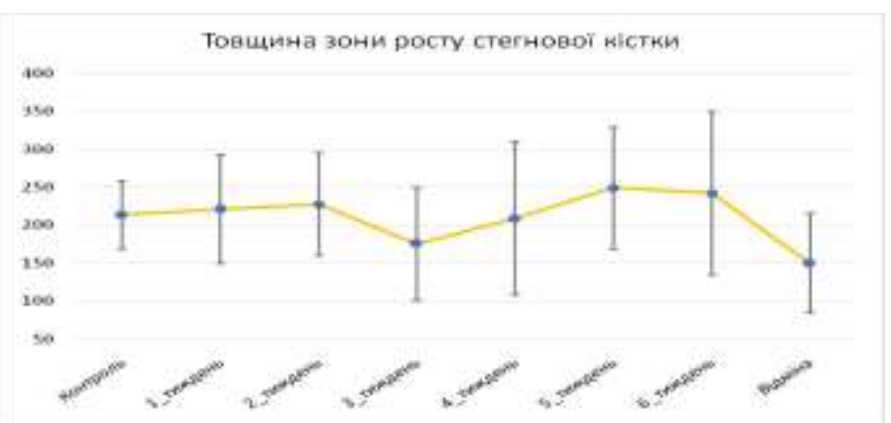

Діаграма 3. Динаміка значення товщини зони росту стегнової кістки.

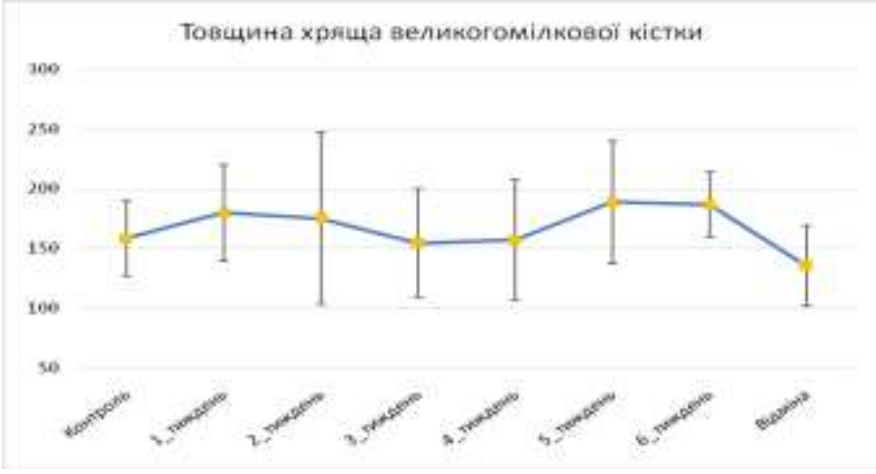

Діаграма 4. Динаміка значення товщини хряща великогомілкової кістки.

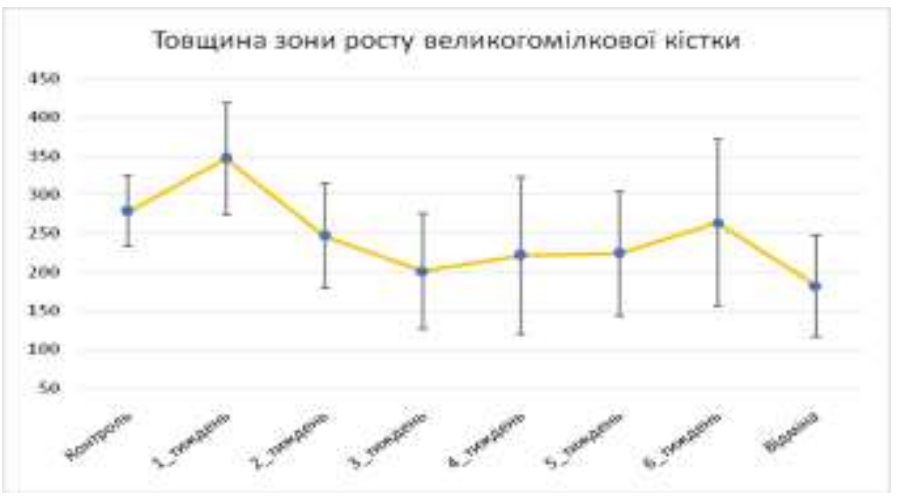

Діаграма 5. Динаміка значення товщини зони росту великогомілкової кістки.

Висновки. 1. Товщина хряща стегнової кістки щурів контрольної групи була найбільшою в ділянці контакту із великогомілковою кісткою та становила 160-180 мкм. Найменша товщина хряща стегнової кістки була у фронтальній ділянці в зоні контакту із надколінником та становила 70-90 мкм. Середнє значення товщини хряща стегнової кістки у тварин контрольної групи становило $144,88 \pm 31,20$ мкм. Зона росту стегнової кістки інтактних тварин на розрізі мала зубчасту форму із коливанням товщини від 97,56 мкм до 315,65 мкм при

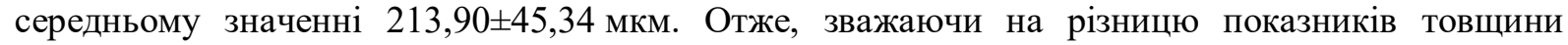
хрящів та зон росту стегнової та великогомілкової кісток у тварин контрольної групи, доцільним буде проводити морфометричний аналіз даних показників у кожній групі окремо.

2. Наприкінці другого тижня середне значення товщини зони росту стегнової кістки щурів наприкінці першого тижня експериментального опіоїдного впливу становило $220,73 \pm 71,91$. I хоча таке збільшення не було підтверджено статистично $(\mathrm{p}=0,51, \mathrm{t}=-0,67)$, однак тенденція до потовщення підтверджується не тільки збільшенням середнього значення, але i значним збільшенням показника стандартного відхилення до 71,91 (45,34 у щурів контрольної групи.

3. Наприкінці третього тижня товщина зони росту великогомілкової кістки наприкінці другого тижня експериментального опіоїдного впливу різко знизилась після збільшення цього показника на попередньому терміні. Середнє значення становило 246,51 433,70 мкм, що було значено менше показника наприкінці першого тижня експерименту, яке становило $346,74 \pm 139,00$ мкм, та

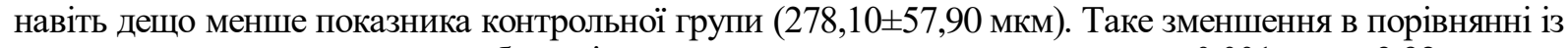
показником контрольної групи було підтверджено статистично - показник $\mathrm{p}<0,001$ при $\mathrm{t}=3,92$. 
4. Наприкінці четвертого тижня товщина зони росту великогомілкової кістки мала тенденцію до збільшення в порівнянні із попереднім терміном, однак залишалась меншою за показник контрольної групи - іiі значення становило 221,51 50,53 мкм, що було достовірно менше при порівнянні із групою контролю - $<<0,001$ при $\mathrm{t}=5,50$.

5. Наприкінці п'ятого тижня хрящ великогомілкової має більшу тенденцію до варіативності товщини - нерівномірності форми у перерізі із потовщеннями до 260-380 мкм, а в окремих зразках товщина досягала 500 мкм. За рахунок цього середнє значення товщини хряща

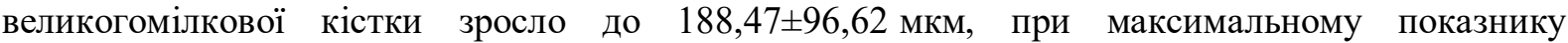
502,94 мкм. Таке збільшення було статистично достовірним при порівнянні із показником контрольної групи ( $<<0,05$ при $\mathrm{t}=-2,07)$.

6. Наприкінці шостого тижня хрящ великогомілкової кістки навпаки - мав нерівномірний характер за товщиною, значення якої коливається від мінімального значення 65,84 мкм до максимального - 554,66 мкм, із окремими ділянками різкого потовщення з нерівномірними випинами в сторону епіфізу, найчастіше в центральній частині та в передній ділянці переходу в зону росту.

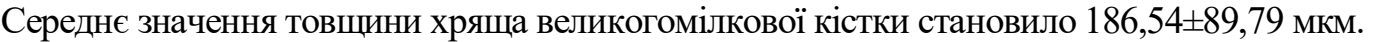

7. В цілому протягом експерименту морфометричні показники хрящів та зон росту кісток щура мають різні тенденції протягом перших термінів із загальною тенденцією до зменшення середніх значень після 3-х тижнів дослідження 3 подальшим переважно наростанням товщини протягом наступних термінів (виключення товщина хряща стегнової кістки, яка зберігає стійку тенденцію до стоншення після 2-го тижня експерименту). Після відміни, на 8-му тижні дослідження, всі параметри мали різке достовірне зменшення у порівнянні із показниками контрольної групи. В контексті вищесказаного особливо показовими є зміни в місці передньої ділянки переходу хряща великогомілкової кістки в зону росту.

\section{ЛІТЕРАТУРА}

1. Ulrich-Vinther, M., Maloney, M. D., Schwarz, E. M., Rosier, R., \& O'Keefe, R. J. (2003). Articular cartilage biology. J Am Acad Orthop Surg, 11(6), 421-430.

2. Eckstein, F., Hudelmaier, M., \& Putz, R. (2006). The effects of exercise on human articular cartilage. $J$ Anat, 208(4), 491-512.

3. Paltov, E. V., Kryvko, Yu. Ya., Zhukovskyi, V.S, Fik, V. B, Vilkhova, I. V., \& Pankiv, M. V. (2018). Pathomorphologic changes in the retina layers at the end of the fourth week of effect. Deutscher Wissenschaftsherold. German Science Herald, 4, 36-39.

4. Voitsenko, K. I., Paltov, Ye. V., Kryvko, Yu. Ya., \& Holeiko, M. V. (2019). Dynamics of morphological changes of structural components of the cartilage coating of the knee joint at the ultrastructure level at the end of the first, second and third weeks of opioid exposure. Open Access Peer-Reviewed Journal Science Review, 1(18), 3-10.

5. Voitsenko, K. I., Kryvko, Yu. Ya., \& Paltov, Ye. V. (2019). Morphological characteristic of structural components of cartilage coating of the knee joint at the ultrastructure level in norm. World Science, 1(41), 7-10.

6. Onisco, R. M., Paltov, Y. V., Fik, V. B., \& Fitkalo, O. S. (2013). Ukraine. Patent No. 76564. Kyiv: Ukrainian Institute of Intellectual Property (Ukrpatent).

7. Abràmoff, M. D., Magalhães, P. J., \& Ram S. J. (2004). Image processing with ImageJ. Biophotonics Int, 11(7), $36-42$.

8. Schneider, C. A., Rasband, W. S., \& Eliceiri, K. W. (2012). NIH Image to ImageJ: 25 years of image analysis. Nat Methods, 9(7), 671-675.

9. Schindelin, J., Arganda-Carreras, I., Frise, E., Kaynig, V., Longair, M., Pietzsch, T. ... Cardona, A. (2012). Fiji: an open-source platform for biological-image analysis. Nat Methods, 9(7), 676-682.

10. Jensen, E., Gundersen, H., \& Østerby, R. (1979). Determination of membrane thickness distribution from orthogonal intercepts. J Microsc, 115(1), 19-33.

11. Coan, P. M., Ferguson-Smith, A. C., \& Burton, G. J. (2004). Developmental Dynamics of the Definitive Mouse Placenta Assessed by Stereology. Biol Reprod, 70(6), 1806-1813.

12. Johnson, L. R., \& Karunakaran, U. D. (2014). How to Choose the Appropriate Statistical Test Using the Free Program "Statistics Open for All" (SOFA). Ann Community Health, 2(2), 54-62.

13. Romais, B. (1953). Microscopic technique. (p. 71-72). Moscow: Medicine. 